\title{
Tanggung Jawab Notaris Pengganti yang Melakukan Perbuatan Melawan Hukum dalam Pembuatan Akta Autentik
}

\author{
I Gusti Agung Ika Laksmi Mahadewi' ${ }^{1}$ I Wayan Novy Purwanto ${ }^{2}$ \\ 1Fakultas Hukum Universitas Udayana, E-mail: agungikalaksmi17@gmail.com \\ 2Fakultas Hukum Universitas Udayana, E-mail: novy_purwanto@unud.ac.id
}

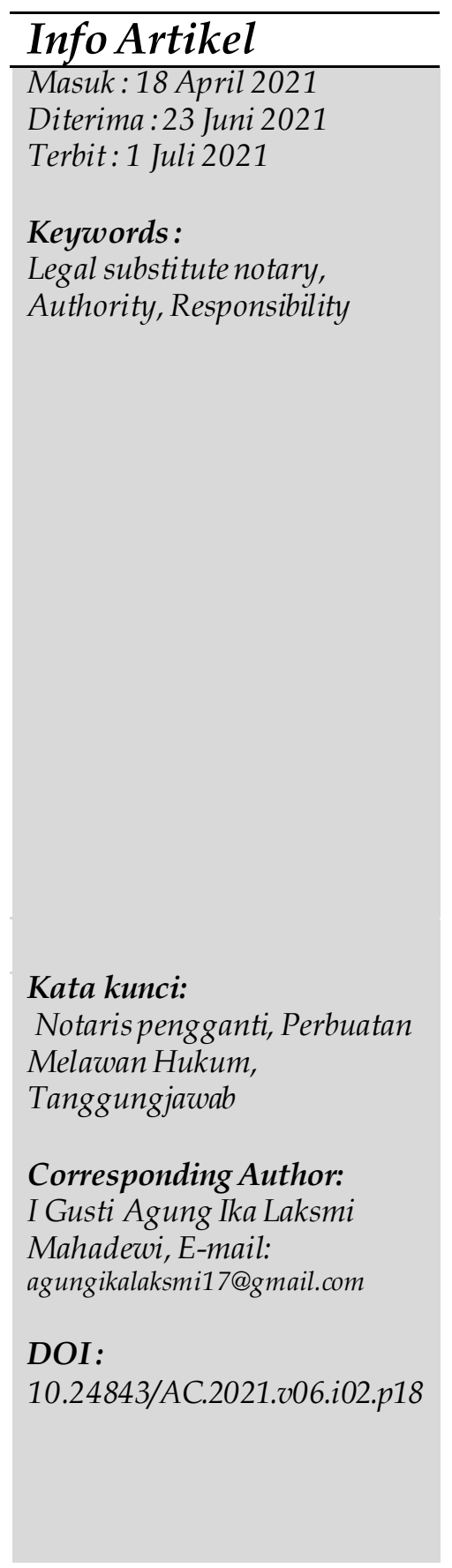

\begin{abstract}
The writing of this article aims to determine the authority of a substitute notary in carrying out the duties and positions of a notary and to find out the responsibilities of a substitute notary when committing an unlawful act in making an authentic deed. This research examines emp ty norms using normative research methods, with a statutory approach, a conceptual approach and an analytical approach. The search for legal materials uses document study techniques, as well as analysis studies using qualitative analysis. The results of this research show that the responsibilities of a Notary Substitute are the same as that of a Notary Public, although they have different competencies, which can be seen through the requirement that a substitute Notary be appointed only with a Bachelor of Law graduates and have worked in a Notary Office. This cannot guarantee that the Substitute Notary will work properly and will not discriminate against the position of the Notary who has responsibility for the deed he made without a time limitand is not associated with the responsibility of the Notary being replaced. The principle of responsibility based on error is the basis for imposing sanctions on a Substitute Notary who is proven to have committed an unlawful actand is responsible for his actions in Civil, Criminal, code of ethics as well as administratively and is not associated with the responsibility of the Notary being replaced.
\end{abstract}

\footnotetext{
Abstrak

Penulisan artikel ini bertujuan untuk mengetahui kewenangan notaris penggantidalam menjalankan tugas sertajabatan notaris dan untuk mengetahui tanggung jawab Notaris Pengganti apabila melakukan perbuatan melawan hukum dalam pembuatan akta autentik. Riset ini mengkaji norma kosong menggunakan metode penelitian normatif, dengan pendekatan perundangundangan, pendekatan konseptual dan pendekatan analisis. Penelusuran bahan hukum menggunakan teknik studi dokumen, serta analisis kajian menggunakan analisis kualitatif. Hasil riset ini menunjukkan bahwa tanggung jawab Notaris Pengganti sama dengan Pejabat Notaris meski memiliki kompetensi yang berbeda yang dapat dilihat melalui syarat diangkatnya notaris pengganti hanya dengan lulusan Sarjana Hukum dan pernah bekerja pada Kantor Notaris. Hal tersebut tidakdapat menjamin bahwa Notaris Pengganti akan bekerja dengan baik dan tidak mendiskriminasijabatan Notaris yang memiliki tanggung jawab
} 
terhadap akta yang dibuatnya tanpa adanya Batasan waktu dan tidak dikaitkan dengan tanggungjawabNotaris yang digantikan. Prinsip pertanggungjawaban berdasarkan kesalahan merupakan dasar pengenaan sanksi kepada Notaris Pengganti yang terbukti melakukan perbuatan melawan hukum dan mempertanggungjawabkan perbuatannya secara Perdata, Pidana, kode etik serta pula secara administrasi dan tidak dikaitkan dengan tanggung jawab Notaris yang digantikan.

\section{Pendahuluan}

Jabatan Notaris merupakan jabatan yang dengan sengaja dibentuk oleh negara guna menjalankan sebagian kewenangan dan tugas negara dibidang hukum khususnya hukum perdata dan atau lapangan hukum pembuktian dengan produk hukumnya berbentuk akta otentik yang mampu membuktikan dengan kekuatan pembuktian sempurna. Notaris dalam menjalankan tugas dan jabatan mempunyai kewenangan dalam membuat akta yang dikategorikan otentik, namun dikecualikan terhadap akta otentik dengan kewenangan membuatnya yang dikususkan pembuatannya kepada penjabat umum lainnya. Dalam pembuatan akta otentik dibagi menjadi 2 (dua), ialah akta otentik dengan ditentukan dan menurut undang-undang yang dimaksudkan untuk terciptanya suatu kepastian hukum, ketertiban administrasi dan pembuatan akta otentik yeng bersumber pada kehendahk dari para pihak yang memiliki kepentingan untuk menciptakan kepastian hak, kewajiban yang diperoleh oleh pihak pihak terkait untuk mencapai kepastian hukum, ketertiban dalam pelaksanaan serta perlindungan hukum jika terjadi suatu sengketa bagi pihak pihak yang membuat akta otentik serta bagi masyarakat pada umumnya. Namun dalam pembuatan akta agar dapat dikategorikan otentik, notaris mempunyai kewajiban untuk memberikan pemahaman kepada pihak yang ingin membuat akta berkaitan dengan apa yang diperbolehkan dimasukkan dan apa yang tidak diperkenankan untuk dimasukkan dalam akta otentik, juga notaris harus memastikan apa yang dicantumkan dan termuat didalam draft akta telah dipahami dan sesuai denga napa yang dikehendaki pihak pihak. Pemahaman terhadap isi akta dilakukan dengan membacakan apa yang tertuang dalam akta yang telah disusun oleh Notaris dihadapan pihak-pihak sebelum akta ditandatangani oleh para pihak. Sehingga pihak- pihak mengenali isi akta yang terbuat oleh notaris serta cocok dengan kehendak mereka. Dengan demikian, seseorang pejabat notaris wajib mempunyai keahlian yang baik agar dapat membuat akta yang dikategorikan autentik berdasarkan Undang-Undang Nomor 2 Tahun 2014 Tentang Perubahan Atas UndangUndang Nomor 30 Tahun 2004 Tentang Jabatan Notaris (selanjutnya disingkat UUJN). Notaris dalam melaksanakan jabatannya, membagikan pelayanan kepada warga wajib mempunyai perilaku yang baik dan tunduk pada peraturan.

Dalam membuat akta otentik, seseorang notaris dituntut berlaku adil, mempunyai kecermatan serta kehati- hatian, perihal ini membutuhkan konsentrasi yang besar serta keadaan raga yang baik. Secara universal kesalahan dalam pembuatan akta otentik diakibatkan sebab kurang konsentrasi sehingga mempengaruhi apa yang dikerjakan 
oleh notaris. ${ }^{1}$ Cuti Notaris diatur dalam Pasal 25 UUJN ialah Notaris mempunyai hak cuti setelah 2 (dua) tahun menjabat. Apabila Notaris tidak menunjuk Notaris Pengganti, protokol notaris dapat diserahkan kepada rekan notaris lain yang wilayah hukumnya sama dengan notaris yang mengambil cuti berdasarkan Pasal 11 ayat (4) UUJN. Perihal tersebut bersumber pada penunjukan oleh Majelis Pengawas Wilayah yang berwenang. Sepanjang masa cuti notaris, protokol notaris dipegang oleh notaris pengganti. Protokol tersebut hendak dikembalikan kepada notaris dikala masa cutinya sudah berakhir. Sepanjang notaris pengganti melaksanakan jabatan notaris, kemungkinan ada terjadinya kesalahan dalam pembuatan akta atau dengan sengaja melakukan perbuatan melawan hukum yang biasa disebut $\mathrm{PMH}$, sehingga akta yang diterbitkan tersebut berpotensi memunculkan permasalahan. Notaris mempunyai kewajiban memberikan konsultasi hukum kepada para pihak yang menghadap. Sangat berarti bagi Notaris ataupun Notaris Pengganti untuk memenuhi syarat khusus dalam UUJN agar apa yang dikehendaki para pihak dalam pembuatan akta tidak melanggar syarat hukum yang berlaku. Produk hukum notaris yang berbentuk akta otentik harus dapat menunjukkan kepastian hukum yang bisa dijadikan alat bukti oleh para pihak untuk memastikan hak serta kewajibannya dengan jelas. UUJN menentukan syarat agar dapat menjadi Notaris Pengganti diatur dalam Pasal 33 (1). Menjadi Notaris pengganti, seorang tidak butuh menempuh Pendidikan strata 2 (dua) kenotariatan, disyaratkan hanya mempunyai ijazah strata 1 ilmu hukum. Waktu bekerja sepanjang 2 tahun serta lulusan Sarjana Hukum tidak bisa menjamin kalau seseorang notaris pengganti telah mempunyai keahlian yang memadai untuk melaksanakan tugas serta jabatan selaku seseorang notaris. Disamping itu, seseorang dengan lulusan strata 1 (satu) ilmu hukum belum memperoleh pemahaman tentang kode etik notaris sebagai upaya melindungi marwah jabatan. Pentingnya Kode Etik Notaris merupakan penunjang serta penghormatan terhadap martabat Jabatan Notaris itu sendiri. ${ }^{2}$ Untuk Memenuhi keotentikan akta notaris serta menghindari terbentuknya sengketa akibat kesalahan dalam prosedur membuat akta, UUJN serta Kode Etik Notaris sudah mengatur, asalkan ditaati serta dilaksanakan oleh pejabat Notaris. Penting untuk mentaati Kote Etik Notaris, agar seseorang notaris dapat melaksanakan tugas serta jabatannya sesuai dengan aturan. Dengan syarat pengangkatan Notaris pengganti yang demikian, kompetensi yang dimiliki notaris pengganti jauh lebih rendah daripada pejabat Notaris sehingga berpeluang besar seorang Notaris Pengganti melakukan perbuatan mewalwan hukum dalam menjalankan jabatan Notaris.

Penelitian yang berkaitan dengan artikel ini, terdahulu dilakukan oleh Riekayanti yang menjelaskan kasus yang melibatkan Notaris Pengganti banyak terjadi di kota Semarang. Beberapa tahun terakhir Notaris pengganti dipanggil ke kantor polisi Kota Semarang dengan kapasitasnya sebagai saksi maupun telah diindikasi sebagai tersangka serta sebagai tahanan. Direktorat Reskrim dan satuan Kota Semarangmencatat sejak tahun 2010 sampai 2015 Jumlah kasus tindak pidana yang melibatkan notaris sebanyak 53 kasus, diantaranya 10 orang merupakan Notaris Pengganti sebagai tersangka dan

${ }^{1}$ Mahendra, M. C. A. Akibat Hukum Terhadap Kesalahan Ketik pada Akta yang Dibuat Notaris. Acta Comitas: Jurnal Hukum Kenotariatan,4(2), 227-236, h. 228, DOI 10.24843/AC.2019.v04.02.p.06

${ }^{2}$ Gitayani, L.P. C. (2018). Penerapan Etika Profesi oleh Notaris dalam Memberikan Pelayanan Jasa Kepada Klien. Acta Comitas: Jurnal Hukum Kenotariatan, 3(3), 426-435, h 428, DOI 10.24843/ AC.2018.v03.i03.p0 3 
sisanya sebagai saksi. ${ }^{3}$ Kasus ini banyak terjadi karena ketidakpahaman seorang Notaris Pengganti terhadap perbuatan hukum yang dibuatkannya akta otentik. Ketidak pahaman ini yang menimbulkan Notaris Pengganti mendiskriminasi akta otentik yang dibuatnya dengan memasukkan perbuatan hukum yang tidak pantas, tidak boleh serta tidak patut dimasukkan kedalam akta otentik sehingga berdasarkan ketentuan Pasal 1365 KUHPerdata menyebabkan terjadinya perbuatan melawan hukum.

Berdasarkan uraian diatas, penulis mengangkat permasalahan yang dirumuskan sebagai berikut: 1) Bagaimanakah kewenangan notaris pengganti dalam menjalankan tugas dan jabatan notaris? 2) Bagaimanakah tanggung jawab Notaris Pengganti apabila melakukan perbuatan melawan hukum dalam pembuatan akta autentik?. Tujuan dalam penulisan jurnal ini untuk memberikan pengetahuan tentang kewenangan notaris pengganti dalam menjalankan tugas serta jabatan notaris dan tanggung jawab Notaris Pengganti apabila melakukan perbuatan melawan hukum dalam pembuatan akta autentik.

Penelitian terdahulu yang berkaitan dengan artikel ini yaitu : Pertama dilakukan oleh Ariy Yandillah, Sihabudin, dan Herlin Wijayanti pada tahun 2015 yang berjudul “Tanggung Jawab Notaris Pengganti Terkait Pembuatan Akta Notaris Yang Merugikan Para Pihak Akibat Kelalaianya".4 Penelitian kedua oleh Aprilia Putri Suhardini, Imanudin dan Sukarmi, tahun 2018 dengan judul "Pertanggungjawaban Notaris Yang Melakukan Perbuatan Melawan Hukum Dalam Pembuatan Akta Autentik".5 Kesamaannya yaitu: penelitian pertama sama sama meneliti tentang tanggung jawab Notaris Pengganti, namun penelitian tersebut berfokus pada tanggung jawab Notaris Pengganti terhadap kelalaiannya dalam membuat akta otentik dan menimbulkan kerugian bagi para pihak sehingga harus dipertanggungjawabkan berdasarkan hukum perdata, pidana, UUJN dan Kode Etik. Sedangkan perbedaannya dengan penelitian yang dilakukan penulis berfokus pada tindakan diskriminasi yang dilakukan Notaris Pengganti terhadap akta yang dibuatnya dengan memasukan unsur-unsur perbuatan melawan hukum kedalam akta autentik. Sehingga bertanggung jawab penuh atas dasar kesalahannya. Penelitian kedua, sama sama membahas perbuatan melawan hukum yang dilakukan dalam pembuatan akta otentik, namun penelitian tersebut berfokus pada tanggungjawab Pejabat Notaris secara langsung, sedangkan perbedaannya dengan penelitian yang penulis lakukan yaitu membahas tanggungjawab Notaris Pengganti terhadap perbuatan melawan hukum yang dilakukan dalam pembuatan akta otentik. Perbedaan tersebut menunjukkan orisinalitas dari penelitian yang penulis lakukan sehingga penting untuk dilakukan penelitian ini guna mengisi kekosongan norma untuk kemajuan dan pembaharuan hukum khususnya pada bidang tanggung jawab notaris pengganti. Dari uraian tersebut, penulis mengangkut judul “Tanggung

\footnotetext{
${ }^{3}$ Riekayanti, H. Y., Ratna, E., \& Prasetyo, M. H. AKIBAT HUKUM AKTA YANG DIBUAT NOTARIS PENGGANTI DI KOTA SEMARANG. NOTARIUS, 13(2), 465-78, h. 466, DOI https:// doi.org/10.14710/nts.v13i2.30506

4 Yandillah, A. (2015). Tanggung Jawab Notaris Pengganti Terkait Pembuatan Akta Notaris Yang Merugikan Para Pihak Akibat Kelalaianya. Kumpulan Jurnal Mahasiswa Fakultas Hukum, h. 1, URL http:// hukum.studentjournal.ub.ac.id/index.php/hukum/article/viewFile/1195/1181 5 Suhardini, A. P., Imanudin, I., \& Sukarmi, S. (2018). Pertanggungjawaban Notaris Yang Melakukan Perbuatan Melawan Hukum Dalam Pembuatan Akta Autentik. Jurnal Akta, 5(1), 261-266, h. 1, DOI http://dx.doi.org/10.30659/akta.v5i1.2610
} 


\section{Jawab Notaris Pengganti Terhadap Perbuatan Melawan Hukum Yang Dilakukan Dalam Pembuatan Akta Otentik".}

\section{Metode Penelitian}

Penelitian ini dilakukan untuk memecahkan permasalahan norma kosong karena UUJN tidak mengatur tanggung jawab Notaris pengganti terhadap perbuatan melawan hukum dalam pembuatan akta otentik, sehingga penelitian ini menggunakan metode penelitian hukum normatif dengan pendekatan peraturan Perundang-Undang, Pendekatan konseptual serta Pendekatan dengan melakukan analisis. Bahan hukum yang digunakan ialah bahan hukum primer (Kitab Undang-Undang Hukum Perdata, Kitab Undang-Undang Hukum Pidana, UUJN ). Bahan hukum sekunder berbentuk buku serta jurnal hukum, dan artikel- artikel dari internet dipakai selaku bahan hukum tersier. Dari bahan-bahan hukum tersebut dilakukan analisis dan hasilnya dijabarkan secara deskriptif. 6

\section{Hasil Dan Pembahasan}

\subsection{Kewenangan Notaris Pengganti dalam Menjalankan Tugas dan Jabatan Notaris}

Sumber kewenangan ada 3 (tiga) yaitu kewenangan atributif, delegatif dan mandat. Jabatan Notaris maupun Notaris pengganti merupakan jabatan yang kewenangannya bersumber dari kewenangan atributif. Sumber kewenangan delegatif dan sumber kewenangan mandat bukan merupakan sumber kewenangan jabatan Notaris/Notaris pengganti. Notaris/Notaris Pengganti tidak diberikan mandat atau perintah oleh pemerintah maupun tidak dilimpahkan wewenang atau delegatif untuk menjalankan fungsi, tugas dan Jabatannya. Kewenangan yang dimiliki Pejabat Notaris atau Notaris Pengganti bersumber dari kewenangan atributif, yaitu kewenangan yang diperoleh atau wewenang yang diberikan langsung melalui peraturan Perundang-Undangan. Jabatan notaris sengaja dibentuk oleh Negara melalui aturan hukum yaitu UUJN Jo. UUJN-P untuk menjalankn sebagian kewenangan negara khususnya dalam lapangan hukum pembuktian. Pengaturan jabatan Notaris juga diatur dalam KUHPerdata yang merupakan peraturan diatas UUJN yaitu dalam Pasal 1868 yang mengatur tentang akta yang dikategorikan otentik.

Akta Notaris yang dikualifikasikan memiliki kekuatan sempurna jika dapat digunakan untuk membuktikan dan tidak diperlukan adanya dukungan untuk membuktikan tindakan lainnya dan dapat memberikan kepastian hukum bagi pihak pihak dan melindunginya dari permasalahan hukum yang akan terjadi dikemudian hari. Pasal 27 UUJN mengatur pengambilan cuti oleh Notaris dilakukan pengajuan tertulis, disertai pengajuan usulan naama untuk ditunjuk sebagai Notaris Pengganti yang akan diangkat dan menjabat sementara selama Notaris berhalangan menjalankan tugas dan jabatannya. Notaris Pengganti diperlukan karena Jumlah Notaris yang menjabat dalam suatu wilayah jabatan dibatasi berdasarkan Pasal 22 UUJN. Penghitungan jumlah Keberadaan Notaris dalam suatu wilayah telah ditentukan dengan kegiatan dunia usaha yang ada di daerah tersebut, jumlah akta yang dibuat oleh masarakat dan jumlah

\footnotetext{
${ }^{6}$ Diantha, I. M. P., \& SH, M. (2016). Metodologi penelitian hukum normatif dalam justifikasi teori hukum. Prenada Media, h. 4-7
} 
penduduk pada wilayah tersbut. Sehingga wajib ditetapkan Notaris Pengganti bila Pejabat Notaris tidak bisa bertugas, sedangkan harus memenuhi kebutuhan warga dalam pembuatan akta otentik, sehingga pelayanan kepada masyarakat dalam pembuatan akta otentik tidak tersendat serta berjalan sebagaimana mestinya. Kewenangan Notaris pengganti berasal dari UUJN ialah diberikan kewenangan atribusi yang melahirkan tanggung jawab serta tanggung gugat yang terletak pada penerima kewenangan menurut undang-undang. ${ }^{7}$

Notaris pengganti dibebankan pertanggungjawaban sesuai Pasal 65 UUJN. Tanggung jawab tersebut dibebankan selama menjabat sampai Notaris Pengganti selesai menjabat dan menyerahkan kembali seluruh protokol Notaris kepada Pejabat Notaris yang digantikannya. Perbuatan melanggar wewenang yang dilakukan oleh Notaris Pengganti tidak dikaitkan dengan Pejabat Notaris yang digantikannya. Kewenangan yang dimiliki Notaris Pengganti dibatasi oleh Pasal 33 ayat (2) UUJN, yaitu hanya selama Pejabat Notaris yang digantikan tersebut berhalangan menjalankan tugas dan jabatannya. Kedudukan notaris atau Lembaga kenotariatan dapat dibedakan dengan profesi lainnya. Tanggung jawab notaris yang tidak adanya batas waktu tersebut tak lepas dari kebijakan negara dalam pembentukan Lembaga kenotariatan. Magister kenotariatan dibentuk oleh negara karena kedudukan jabatan notaris dibentuk untuk menjalankan sebagian kewenangan negara dalam lapangan hukum pembuktian dengan produk hukumnya berupa akta otentik yang kekuatan hukumnya diletakkan pada kualifikasi sempurna. Tidak ada satupun profesi yang berhubungan dengan hukum memiliki Lembaga magister kenotariatan seperti kehakiman, kejaksaan, kepolisian dan lain sebagainya. Karena akta otentik diletakkan pada kualifikasi sempurna, maka pembuat akta otentik tersebut harus memiliki sifat sifat mendekati kesempurnaan. Untuk mewujudkna hal tersebut maka diadakan kode etik Jabatan Notaris dan UUJN agar akta otentik yang dibuat sesuai dengan apa yang dikehendaki. Permasalahan hukum yang dihadapi oleh notaris Sebagian besar bermula dengan pelanggaran terhadap kode etik jabatan notaris karena rendahnya pengetahuan seorang notaris sehingga memaknai kode etik dengan pandangan yang menyimpang dari apa yang dikehendaki oleh perkumpulan Ikatan Notaris Indonesia.

Batas kewenangan notaris dalam membuat akta sebagai pejabat pembuat akta berakhir saat slainan akta yang dibuatnya telah diserahkan kepada para pihak. Setelah Salinan akta diserahkan, maka masuk kedalam ranah hukum pembuktian karena akta tersebut dijadikan bukti suatatu kepemilikan hak maupun kewajiban oleh para pihak. Sehingga notaris berhenti menjadi pejabat pembuat akta dan berganti menjadi penjaga warkah negara. Dikatakan sebagai penjaga warkah negara karena minuta yang dibuatnya telah menjadi dokumen rahasia negara, tidak dapat ditunjukkan ke pihak manapun kecuali para pihak dan berdasarkan penetapan pengadilan. Tugas sebagai penjaga warkah negara ini akan berakhir saat pelaksanaan dari isi akta sudah melampaui waktu, contohnya perjanjian sewa 5 tahun, dan waktu sewa tersebut sudah berakhir, maka notaris berhenti menjadi penjaga warkah negara. Saat notars memasuki masa pensiun maka notaris berhenti menjadi penjaga warkah negara dengan menyerahkan protokol

${ }^{7}$ Mido, M. T. C., Nuriaya, I. N., \& Safa' at, R. (2018). Tanggung Jawab Perdata Notaris Terhadap Akta yang di Bacakan oeh Staf Notaris di Hadapan Penghadap. Lentera Huum, 5(1), 156-173, h. 156, DOI 10.19184/ejlh.v5i1.6288 
notaris berupa minuta tersebut kepada notaris aktif yang ditunjuknya dengan pertanggungjawabannya hingga helaan napas terakhir. ${ }^{8}$

Dengan demikian, Notaris pengganti harus memiliki kompetensi yang setara dengan Notaris yang digantikannya. Agar notaris pengganti memiliki kompetensi dan pemahaman tersebut maka kekosongan norma dalam UUJN harus dirumuskan dengan memasukkan tes atau ujian kelayakan Notaris Pengganti tentang pemahamannya terhadap Kote Etik Notaris dan UUJN sehingga ketentuan terhadap syarat pengangkatan Notaris Pengganti yang berupa lulusan strata 1(satu) dan bekerja di kantor notaris menapun selama 2 tahun berkesinambungan ditambahkan dengan pelatihan dan ujian terhadap kode etik notaris dan UUJN.

\subsection{Tanggung Jawab Notaris Pengganti apabila Melakukan Perbuatan Melawan Hukum dalam Pembuatan Akta Autentik}

Secara umum, permasalahan dalam pembuatan akta otentik bersumber dari dua hal, yang pertama Tindakan mendiskriminasi akta otentik dan kedua Tindakan mendiskriminasi jabatan notaris. Kedua hal tersebut merupakan sumber dari terjadinya permasalahan yang dapat menyeret baik notaris maupun para pihak ke jalur hukum. Tindakan mendiskriminasi akta otentik merupakan Tindakan yang sengaja dilakukan dengan oleh para pihak dengan berbuat tidak sesuai dengan kesepakatan. Pembuatan akta otentik dilakukan sesuai dengan ketentuan UUJN. Notaris mengkonstatir yaitu melakukan ferifikasi terhadap fakta-fakta empiris yang dikemukakan oleh penghadap menjadi fakta hukum yang akan dijadikan dasar untuk pembuatan akta otentik. Setelah itu, notaris mengkonstatir perbuatan hukum tersebut dapat dibuatkan akta yang sepatutnya ditentukan oleh undang-undang. contohnya Jika fakta hukumnya mengarah kepada hibah, maka notaris harus memastikan para pihak tidak melakukan tarnsaksi membayar sebelumnya. Jika ditemukan adanya transaksi membayar maka tidak dapat dibuatkan akta hibah. Selanjutnya notaris melakukan Tindakan forleden dengan Menyusun draft akta. Sebelum draft ditandatangani, dibacakan terlebih dahulu, kemudian terakhir notaris mengeluarkan Salinan akta yang diberikan kepada para pihak agar dapat dimanfaatkan sebagaimana mestinya. Seluruh langkah-langkah dalam pembuatan akta diatas telah dibuat sesuai dengan ketentuan UUJN, dan tidak ada permasalahan dalam proses pembuatan akta. Namun permasalah muncul ketika akta sudah digunakan oleh para pihak, yang diakibatkan kelalaian para pihak itu sendiri tidak bertindak sesuai dengan apa yang dituangkan dalam akta, karena kerugian timbul akibat para pihak yang mendiskriminasi akta otentik tersebut dalam arti para pihak tidak melaksanakan kewajiban-kewajiban yang seharusan. Maka tidak bisa dikatakan bahwa kerugian tersebut akibat dari cacatnya akta otentik.

Tindakan mendiskriminasi jabatan notaris hanya dapat dilakukan oleh notaris itu sendiri. Seorang notaris pengganti dengan pengangkatannya yang sama dengan pengangkatan jabatan notaris, disumpah dan tunduk terhadap perkumpulan Ikatan Notaris Indonesia dan juga Kode Etik notaris juga berpotensi besar melakukan diskriminasi terhadap jabatan yang diembannya walaupun berstatus notaris pengganti

${ }^{8}$ Ariawan, P. B. (2018). Kepastian Hukum Wilayah Jabatan Notaris Sebagai Pemegang Protokol Notaris Yang Berakhir Masa Jabatannya. Acta Comitas: Jurnal Hukum Kenotariatan, 3(2), 326335, h. 329, DOI 10.24843/ AC.2018.v03.i02.p09 
yang memiliki jangka waktu jabatan. Salah satu tindakan mendiskriminasi jabatan notaris dapat dilakukan dengan sengaja dimasukkan perbuatan melawan hukum dalam pembuatan akta otentik demi mendapatkan keuntungan tertentu yang menjadi tujuannya. Aksi diskriminasi jabatan notaris yang bisa dikategorikan demikian diatur dalam Pasal 1365 KUHPerdata dengan unsur- unsur yang wajib terpenuhi ialah terdapatnya perbuatan, perbuatan itu melawan hukum, terdapatnya kerugian, serta terdapatnya ikatan karena akibat kelalaiannya..$^{9}$ Adanya perbuatan yang dilakukan oleh notaris pengganti selama menjalankan jabatan notaris, perbuatan yang dilakukan tersebut merupakan perbuatan yang melangar hukum. Pada awalnya, diartikan secara sempit yaitu perbuatan yang melanggar ketentuan yang berlaku sebagai undangundang saja. Namun teori hukum terus berkembang dan memperluas pengertian dari perbuatan melawan hukum.

Salah satu kasus yang terkenal menjadi tonggak penting dalam perluasan pengertian perbuatan melawan hukum yaitu kasus Lindenbaum melawan Cohen. dalam perkara tersebut terjadi persaingan yang tidak sehat antara dua kantor percetakan yang dimiliki oleh Lindenbaum Cohen. kantor percetakan milik Lindembaum memiliki banyak pelanggan dan setiap harinya selalu ramai menerima pesanan, sedangkan kantor percetakan milik Cohen selalu sepi dan tidak memiliki pelanggan. Seiring berjalannya waktu, Cohen memiliki niatan yang tidak baik yaitu dengan membujuk pegawai kantor milik Lindenbaum untuk memberitahukan nama-nama pelanggan dan juga penawaran yang diberikan. Proses peradilan berlangsung, pada tingkat pertama Cohen mengalami kekalahan, pada tingkat banding sebaliknya, Lindenbaum yang mengalami kekalahan karena Tindakan Cohen dianggap tidak melanggar pasal dari peraturan perundang undangan, masih berpedoman pada pengertian perbuatan melawan hukum dalam artian sempit. Namun di tingkat Mahkamah Agung Belanda, melalui putusan Hoge Raad tertanggal tiga puluh satu Januari Tahun seribu Sembilan ratus Sembilan belas, Lindenbaum yang memenangkan perkara. Hoge Raad mengeluarkan pengertian PMH dalam Pasal 1401 BW Belanda diperluas pemaknaannya, termasuk dalam perbuatan yang berdampak pada pelanggaran hak orang, bertantangan dengan kewajiban dalam bidang hukum pelaku dan dengan norma kesusilaan. Unsur berikutnya yang harus dipenuhi yaitu adanya kerugian yang dialami oleh para pihak berdasarkan perbuatan yang dilakukan oleh notaris pengganti tersebut. Dari semua perbuatan tersebut timbul keterkaitan PMH dengan dampak yang ditimbulkan memang benar berdasarkan hal yang dilakukan oleh notaris pengganti tersebutlah para pihak mengalami kerugian.

Oleh sebab akta notaris ialah sesuatu perjanjian, hingga syarat menimpa ketentuan sahnya perjanjian, digunakan untuk memfilter untuk pertama kalinya sebelum dikonstatir menjadi akta bahwa fakta-fakta empiris yang dikemukakan oleh para pihak dapat menjadi fakta hukum dan kemudian dikonstatir oleh Notaris. ${ }^{10}$ Pasal 1320 KUHPerdata menentukan empat syarat yang harus dipenuhi agar terjadinya persetujuan yang sah. Syarat pertama yaitu kesepakatan para pihak, Notaris dalam mengkonstatir akta harus menentukan patut atau tidak patut apa yang telah disepakati para pihak tersebut. Syarat kedua yaitu kecakapan para pihak dalam membuat suatu

\footnotetext{
9 Saffanah, A. B., \& Rizkianti, W. (2021). KEKUATAN HUKUM PEMBUKTIAN AKTA NOTARIS AKIBAT PENYALAHGUNAAN KEADAAN. Legal Standing: Jurnal Ilmu Hukum, 5(1), 11-24, h. 12, DOI 10.24269/1s.v5i1.3570

10 Abdulkadir, M. (2010). Hukum Perusahaan Indonesia. Bandung: PT. Citra Aditya Bakti, h. 23.
} 
perikatan, Notaris menentukan para pihak sudah dapat atau tidak dapat membuat suatu pengikatan dengan akta otentik. Syarat berikutnya yaitu pokok persoalan dan sebab yang tidak dilarang, Notaris harus menentukan boleh atau tidak boleh objek yang diperjanjikan para pihak tersebut. Dari uraian tersebut Notaris dapat mengetahui konsekuensi dalam pembuatan akta otentik yang pada umumnya jika syarat subjektif tidak patut, oleh pihak yang berkepentingan dan mengalami kerugian akibat pelaksanaan dari perjanjian tersebut dapat membatalkan. ${ }^{11}$

Tanggung jawab Notaris Pengganti jika terdapat unsur kesalahan yang dilakukannya dalam pembuatan akta otentik, secara umum ada empat bentuk pertanggungjawaban. Tanggung jawab secara Perdata dengan menggunakan konstruksi yuridis PMH Pasal 1365 KUHPerdata berupa mengganti biaya kerugian. Pasal 1320 KUHPerdata juga dijadikan dasar dalam pembuatan akta autentik dengan mematuhi syarat sahnya perjanjian yaitu musabab yang halal. Kerugian yang dialami dan harus dipertanggungjawabkan secara perdata belum diatur dalam UUJN, sehingga untuk menegakkan hukumnya kembali pada KUHPerdata. Kedua, UUJN-P mengatur tanggung jawab administasi yang harus dipertanggungjawabkan jika Notaris/Notaris Pengganti melanggar ketentuan yang telah ditetapkan dalam UUJN-P yang berupa peringatan tertulis terhadap perbuatan tersebut, pemberhentian yang bersifat sementara, secara hormat, tidak hormat, dan pemecatan dari jabatan Notaris. Jika perbuatan Notaris Pengganti memenuhi unsur perbuatan melawan hukum yang mengandung unsur pemalsuan dan penipuan maka dapat dimintakan tanggung jawab secara Pidana. Dengan demikian, kekosongan norma terkait pertanggungjawaban perdata Notaris Pengganti terhadap tindakan mendiskriminasi akta autentik yang dibuatnya berupa memasukkan hal-hal yang tidak pantas, tidak boleh serta tidak patut kedalam akta otentikyang dibuatnya sehingga merugikan pihak, harus mempertanggungjawabkan perbuatannya berupa mengganti biaya terhadap kerugian yang dialami para pihak.

\section{Kesimpulan}

Notaris yang mengambil cuti harus menunjuk Notaris Pengganti dengan tujuan agar kebutuhan masarakat terhadap pembuatan akta otentik di sesuatu daerah senantiasa terpenuhi. Kewenangan seseorang Notaris Pengganti sama dengan Pejabat Notaris, namun syarat diangkatnya notaris penggantin hanya dengan lulusan Sarjana Hukum dan pernah bekerja pada Kantor Notaris. Seseorang Notaris Pengganti berpotensi mendiskriminasi jabatan Notaris dengan memasukan hal- hal yang tidak pantas, tidak boleh serta tidak patut dimasukkan kedalam akta otentik sehingga berdasarkan ketentuan Pasal 1365 KUHPerdata menyebabkan terjadinya perbuatan melawan hukum. Pertanggungjawaban Notaris Pengganti secara perdata berupa ganti kerugian belum diatur dalam UUJN, sehingga penegakan hukumnya kembali menggunakan KUHPerdata. Pertanggungjawaban secara administasi UUJN-P berupa peringatan tertulis terhadap perbuatan tersebut, pemberhentian yang bersifat sementara, secara hormat, tidak hormat, dan pemecatan dari jabatan Notaris. Pertanggungjawaban secara PidanajJika perbuatan Notaris Pengganti memenuhi unsur Pidana seperti pemalsuan dan penipuan.

\footnotetext{
${ }^{11}$ Hernoko, A. Y., \& SH, M. (2019). Hukum Perjanjian. Prenada Media, h, 4.
} 


\section{Daftar Pustaka}

\section{Buku}

Abdulkadir, M. (2010). Hukum Perusahaan Indonesia. Bandung: PT. Citra Aditya Bakti.

Diantha, I. M. P., \& SH, M. (2016). Metodologi penelitian hukum normatif dalam justifikasi teori hukum. Prenada Media.

Hernoko, A. Y., \& SH, M. (2019). Hukum Perjanjian. Prenada Media.

\section{Jurnal}

Ariawan, P. B. (2018). Kepastian Hukum Wilayah Jabatan Notaris Sebagai Pemegang Protokol Notaris Yang Berakhir Masa Jabatannya. Acta Comitas: Jurnal Hukum Kenotariatan, 3(2), 326-335, DOI 10.24843/ AC.2018.v03.i02.p09

Gitayani, L. P. C. (2018). Penerapan Etika Profesi oleh Notaris dalam Memberikan Pelayanan Jasa Kepada Klien. Acta Comitas: Jurnal Hukum Kenotariatan, 3(3), 426-435, DOI 10.24843/AC.2018.v03.i03.p0 3

Mahendra, M. C. A. Akibat Hukum Terhadap Kesalahan Ketik pada Akta yang Dibuat Notaris. Acta Comitas: Jurnal Hukum Kenotariatan, 4(2), 227-236, DOI 10.24843/AC.2019.v04.02.p.06

Mido, M. T. C., Nurjaya, I. N., \& Safa'at, R. (2018). Tanggung Jawab Perdata Notaris Terhadap Akta yang di Bacakan oeh Staf Notaris di Hadapan Penghadap. Lentera Huum, 5(1), 156-173, h. 156, DOI 10.19184/ejlh.v5i1.6288

Riekayanti, H. Y., Ratna, E., \& Prasetyo, M. H. Akibat Hukum Akta Yang Dibuat Notaris Pengganti Di Kota Semarang. NOTARIUS, 13(2), 465-78, DOI https://doi.org/10.14710/nts.v13i2.30506

Suhardini, A. P., Imanudin, I., \& Sukarmi, S. (2018). Pertanggungjawaban Notaris Yang Melakukan Perbuatan Melawan Hukum Dalam Pembuatan Akta Autentik. Jurnal Akta, 5(1), 261-266, DOI http://dx.doi.org/10.30659/akta.v5i1.2610

Saffanah, A. B., \& Rizkianti, W. (2021). KEKUATAN HUKUM PEMBUKTIAN AKTA NOTARIS AKIBAT PENYALAHGUNAAN KEADAAN. Legal Standing: Jurnal Ilmu Hukum, 5(1), 11-24, h. 12, DOI 10.24269/ls.v5i1.3570

Yandillah, A. (2015). Tanggung Jawab Notaris Pengganti Terkait Pembuatan Akta Notaris Yang Merugikan Para Pihak Akibat Kelalaianya. Kumpulan Jurnal Mahasiswa Fakultas Hukum, h. 1, URL http://hukum.studentjournal.ub.ac.id/index.php/hukum/article/viewFile/119 $\underline{5 / 1181}$

\section{Peraturan Perundang-undangan}


Undang-Undang Nomor 2 Tahun 2014 Tentang Perubahan Atas Undang-Undang Nomor 30 Tahun 2004 Tentang Jabatan Tambahan Lembaran Negara Republik Indonesia Nomor 5491

Kitab Undang-Undang Hukum Perdata

Kitab Undang-Undang Hukum Pidana 